\title{
ANTIFUNGAL AND ANTIOXIDANT PEPTIDES FROM OIL PALM MESOCARPS
}

BENJAMIN LAU YII CHUNG ${ }^{1 *}$; ABRIZAH OTHMAN and UMI SALAMAH RAMLI'

\begin{abstract}
Phytochemicals and bioactive peptides have been discovered in oil palm organs such as kernel and leaf, but there is no documented study in isolating peptides with bioactivities from fruit mesocarps. In this work, we aimed to determine the bioactivity of the peptides derived from hydrolysis of oil palm fruit mesocarps. The fruit mesocarps were subjected to enzyme hydrolysis using trypsin and pepsin, followed by separation of these peptides through liquid chromatography-tandem mass spectrometry (LC-MS/MS) and database searching. Analysis of bioactivity from 25\% and 30\% fractions (trypsinised), and 10\% and 30\% fractions (pepsinised) showed inhibitory effect towards the growth of Ganoderma boninense. In antioxidant assay, only nonfractionated protein hydrolysate with trypsin and pepsin showed a scavenging activity of $17.7 \%-22.3 \%$ for 2,2-diphenyl-1-picrylhydrazyl. We further determined the possible occurrence of antimicrobial activity in silico by matching the experimental peptide sequences to known bioactive peptides. Four antimicrobial peptides were found in fractionated mesocarp hydrolysates using trypsin and pepsin. These bioactive peptides had molecular masses of less than 4-5 kiloDalton $(\mathrm{kDa})$ and made of 11-39 amino acid residues. A total of 23\%-54\% hydrophobic amino acids were found within these sequences. The results showed that the oil palm mesocarps contained peptides with various bioactivities that could be bioprospected into functional constituents with health and crop protection benefits.
\end{abstract}

Keywords: antifungal, bioactive peptides, enzyme hydrolysis, Ganoderma boninense, oil palm.

Received: 24 June 2021; Accepted: 15 November 2021; Published online: 28 January 2022.

\section{INTRODUCTION}

Crude palm oil (CPO) extraction from fruit bunches in palm oil mills around Malaysia generate waste by-products in the form of solid (palm kernel shells, mesocarp fibres and empty fruit bunches-EFB) and liquid (palm oil mill effluent). In 2019, there were 452 palm oil mills in operation throughout Malaysia, capable to produce 112.91 million tonnes of fresh fruit bunches (FFB) annually (Kushairi and Mohd Din, 2020). Chavalparit (2006) reported that an average value of waste generation rate per tonne

\footnotetext{
1 Malaysian Palm Oil Board,

6 Persiaran Institusi, Bandar Baru Bangi,

43000 Kajang, Selangor, Malaysia.
}

* Corresponding author e-mail: benjamin@mpob.gov.my
FFB from palm oil mill in Thailand were $140 \mathrm{~kg}$ of fibre, $60 \mathrm{~kg}$ of shells, $240 \mathrm{~kg}$ of EFB and $42 \mathrm{~kg}$ of decanter cake. Abas et al. reported that these byproducts could reach 70-80 million tonnes per year (Abas et al., 2011). Irvan (2018) also stated that for every tonne of $\mathrm{CPO}$ produced, 0.9 tonne of $\mathrm{EFB}$, 0.6 tonne of mesocarp fibres and 0.27 tonne of palm kernel shells are generated. This huge amount of waste by-products must be treated efficiently or used as biomass to reduce their undesired impacts to the environment.

Mesocarp fibres are generated from mesocarp pressed cake after the removal of nuts and pulp oil (Sabil et al., 2013; Sreekala et al., 1997). Together with EFB and palm kernel shells, the fruit fibres can be considered harmful waste to the surrounding 
environment, if released untreated. These fibres are harder to dispose and normally discarded in the palm oil mills as wastes or used as boiler fuel to produce steam and generating power due to their low moisture content compared to other biomass residues such as EFB. However, mesocarp fibres have low carbon content and therefore, require a remarkably high load to generate power energy, compared to coal. Mesocarp fibres also have low heating value, rendering it difficult to be utilised (Pereira et al., 2020).

Bio-based products are a growing trend in industrial crops. The increasing need for these products is the driving force for the growth of functional food market. Bioactive peptides with antioxidant properties have been indicated as one of the key ingredients in health-promoting foods. The peptides work to lessen the effects of oxidative stress and lipid peroxidation caused by free radicals in human body and food products (Tadesse and Emire, 2020). A demand for less detrimental agricultural pesticides with reduced detrimental effects for crop protection is also pushing for the emergence of the peptide-based biopesticide industry. Biopesticides work similarly with chemical pesticides but not toxic and damaging to the environment. The oil palm industry is currently being threatened by Ganoderma boninense-induced basal stem rot disease. Biofungicides could provide an alternative to the management of this disease without the use of chemical-based control agents.

Mesocarp pressed cake and fibres are readily available raw materials for the extraction of bioactive peptides with antioxidant and antifungal properties. Through this technology, a downstream processing technology to convert mesocarp-based materials into value added natural product can be developed. Bioactive peptides represent specific sequences of amino acids that possess biological activity with several health effects and potential applications in nutraceutical industry. These peptides can be obtained from a chain of procedures, including cell lysis and protein extraction and enzymatic hydrolysis. Mesocarp fibres can have economic values as they can be used as sources of these biomaterials. Protein hydrolysates from palm kernel cake had been found to exhibit good angiotensin converting enzyme (ACE)-inhibitory activity between $22.9 \%$ and $70.9 \%$ (Zarei et al., 2015), antiradical capacity (Ng et al., 2013) and antibacterial activity (Tan et al., 2013). It is therefore rationale to investigate if mesocarp tissues also contain other natural occurring peptides to be developed as bioactive defense against harmful environments. The current process using fruit mesocarp could be adapted to produce bioactive peptides from the abundant mesocarp pressed cake and fibres. To our best knowledge, there is no reported use of oil palm fruit mesocarp as raw material to produce protein hydrolysate, nor is there any published work on the bioactive properties of the protein hydrolysate from this important oil crop.

\section{MATERIALS AND METHODS}

\section{Plant Materials}

Ripe Elaeis guineensis (oil palm) fruitlets $\left(20^{\text {th }}\right.$ week after anthesis) were used as the source of proteins for enzyme hydrolysis. The fruit mesocarps from the fruitlets were sliced to about $2 \mathrm{~cm}$ in length, snap frozen in liquid nitrogen and stored at $-80^{\circ} \mathrm{C}$.

\section{Protein Extraction}

Protein extraction was performed according to Lau et al. (2015). Five $\mathrm{g}$ of sliced fruit mesocarps were ground in $15 \mathrm{~mL}$ of acetone containing $10 \%$ trichloroacetic acid and $1 \mathrm{mM}$ dithiothreitol. The slurry was then centrifuged at $13000 \mathrm{~g}$ for $10 \mathrm{~min}$ at $4^{\circ} \mathrm{C}$ (RA-300 rotor, Kubota 7820, Kubota Corporation, Tokyo, Japan). The washing step was repeated prior to addition of $15 \mathrm{~mL}$ of $80 \%$ methanol containing $0.1 \mathrm{M}$ ammonium acetate. The slurry was mixed and centrifuged as before. The precipitated mesocarp pellet was washed with $15 \mathrm{~mL}$ of $80 \%$ acetone. The mixture was centrifuged at 13 $000 \mathrm{~g}$ for $10 \mathrm{~min}$ at $4^{\circ} \mathrm{C}$. Pellet was re-suspended in $15 \mathrm{~mL}$ of extraction buffer containing $0.7 \mathrm{M}$ sucrose, $1 \mathrm{M}$ Tris- $\mathrm{HCl}, \mathrm{pH} 8.3,5 \mathrm{M} \mathrm{NaCl}, 50 \mathrm{mM}$ DTT, and a tablet of Roche protease inhibitors. The resuspension was sonicated in ultrasonic bath for $15 \mathrm{~min}$ (Townson Mercer Ltd., Stretford, United Kingdom). The mixture was then sieved through two layers of Miracloth (Calbiochem, EMD Millipore Corporation, Billerica, MA, USA) to isolate the non-macerated plant materials. An equal volume of fresh $50 \mathrm{mM}$, pH 8.0 Tris-saturated phenol $(15 \mathrm{~mL})$ was added to the mixture, mixed, and centrifuged at $15000 \mathrm{~g}$ for $15 \mathrm{~min}$ at $4^{\circ} \mathrm{C}$. Proteins in the upper phase were precipitated by adding 5 volumes of cold ammonium acetate-saturated methanol and incubated at $-20^{\circ} \mathrm{C}$ overnight before being centrifuged at $15000 \mathrm{~g}$ for $15 \mathrm{~min}$ at $4^{\circ} \mathrm{C}$. The protein pellet was rinsed with ammonium acetate-saturated methanol and washed twice with $10 \mathrm{~mL}$ of $80 \%$ acetone. The protein pellet was air-dried.

\section{Protein Hydrolysis and Fractionation}

Pellet was solubilised in $50 \mathrm{mM}$ Tris- $\mathrm{HCl}, \mathrm{pH}$ 8.0 (for trypsin) or $50 \mathrm{mM} \mathrm{KCl}, \mathrm{pH} 2.0$ (for pepsin). A $1 \mathrm{mg}$ of trypsin or pepsin was added to $50 \mathrm{mg}$ of proteins. The mixture was incubated for $24 \mathrm{hr}$ with agitation rate of $300 \mathrm{rpm}$ (Innova 42, New Brunswick Scientific Co. Inc., CT, USA). Reaction 
was stopped by heating at $100^{\circ} \mathrm{C}$ for $10 \mathrm{~min}$. The hydrolysed peptides were filtered with $10 \mathrm{kDa}$ centrifugal filters (Amicon Ultra, Merck Millipore Ltd., County Cork, Ireland), purified with C18 disk and fractionated through sequential elution with $5 \%-80 \%$ acetonitrile.

\section{2,2-Diphenyl-1-Picrylhydrazyl (DPPH) Free Radical Scavenging Activity Assay}

A volume of $50 \mathrm{~mL}$ of DPPH solution was prepared using $1.25 \mathrm{mg}$ of 2,2-diphenyl-1picrylhydrazyl and 50\% methanol. An assay standard of $1 \mathrm{~mL}$ was prepared using $25 \mathrm{mg}$ gallic acid and $5 \mathrm{~mL}$ of double-distilled water $\left(\mathrm{ddH}_{2} \mathrm{O}\right)$. A volume of $15 \mu \mathrm{L}$ of assay standard or sample was mixed with $975 \mu \mathrm{L}$ DPPH solution. Absorbance at $515 \mathrm{~nm}$ was read every $20 \mathrm{~s}$ for 12 cycles (Infinite M200, Tecan, Mannedorf, Switzerland). The antioxidant activity was expressed as percentage of $\mathrm{DPPH}$ free radical scavenging activity $\left(\% \mathrm{DPPH}_{\mathrm{SC}}\right)$ and calculated using the Equation (1):

$\% \mathrm{DPPH}_{\mathrm{SC}}=\left(\mathrm{ABS}_{\text {blank }}-\mathrm{ABS}_{\text {sample }}\right) /\left(\mathrm{ABS}_{\text {blank }} \times 100 \%\right)$

Where $\mathrm{ABS}_{\text {blank }}$ is the absorbance value of blank at $t=195 \mathrm{~s}$ and $\mathrm{ABS}_{\text {sample }}$ is the absorbance value of protein hydrolysate. Gallic acid at a concentration of 0-10 $\mu \mathrm{g} \mathrm{mL}^{-1}$ was used as the assay standard.

\section{Antifungal Assay}

A volume of $100 \mu \mathrm{L}$ of potato dextrose broth was added into the well of a 96-well microtiter plate. The potato dextrose broth was mixed with $10 \mu \mathrm{L}$ of sample in the well. A plug of the G. boninense fungus, with a diameter of $5 \mathrm{~mm}$, was added into the well. In this assay, well with a plug of the $G$. boninense fungus without the sample was used as a positive control. The well containing just the potato dextrose broth was used as a negative control. The plate was incubated in dark at $27^{\circ} \mathrm{C}$. Growth was observed until Day 7.

\section{Liquid Chromatography-tandem Mass Spectrometry}

Separation and spectra acquisition of the peptides was conducted with a Thermo EASY-nano liquid chromatography 1200 System, coupled to a Thermo Q Exactive Plus mass spectrometer (Thermo Scientific, MA, USA). The dried peptide digests were reconstituted in $30 \mu \mathrm{L}$ of $0.1 \%$ formic acid and $5 \%$ acetonitrile. A digest volume of $2 \mu \mathrm{L}$ was injected into an Acclaim PepMap 100 C18 reversed phase column $(3 \mu \mathrm{m}, 0.075 \times 250 \mathrm{~mm}$ ) (Thermo Scientific, MA, USA). The column was equilibrated with $0.1 \%$ formic acid (Mobile phase A) and $80 \%$ acetonitrile containing $0.1 \%$ formic acid (Mobile phase B). Gradient of 5\%-35\% in 90 min was applied at a flow

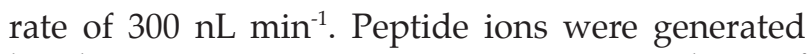
by electrospray ionisation using a spray voltage of 1900 V. Peptide precursor survey scan with a mass ranged from $\mathrm{m} / \mathrm{z} 310-1800$ and resolving power of 70000 was acquired. Only peptide precursors with charge state of 2-7 were chosen for tandem MS. Tandem MS conditions consisted of rapid scan rate using a resolving power of 17500 and $0.7 \mathrm{~m} / \mathrm{z}$ isolation window. Precursors were fragmented using collision induced and high-energy collision induced at normalised collision energy of $28 \%$, respectively. Mass range scanned was from $m / z$ 110-1800.

\section{Data Analysis}

Data acquisitions in positive mode were executed with Thermo Scientific Tune. Generated raw data was processed with Thermo Scientific Proteome Discoverer, version 2.2 (Thermo Scientific, MA, USA). Tandem mass spectra were searched with SEQUEST HT engine against antimicrobial peptide FASTA sequences obtained from the Antimicrobial Peptide Database (APD) (Wang et al., 2016) to determine peptide with bioactivity. Mass tolerances for peptide and product ions were set to $20 \mathrm{ppm}$ and $0.5 \mathrm{Da}$. Trypsin or pepsin with customised cleavage sites was designated as the protease with two missing cleavages was allowed. Carbamidomethylation on cysteine was set as the static modification while oxidation of methionine, deamidation of asparagine and glutamine, and acetyl N-terminal modifications were searched as dynamic modifications. All peptide spectral matches were validated using the Percolator (component of Proteome Discoverer) based on $q$-value at a $1 \%$ false discovery rate.

\section{RESULTS}

The process to convert the oil palm mesocarps to produce bioactive peptides comprised of a series of steps from protein extraction to fractionate the obtained protein hydrolysates using enzymatic hydrolysis (Figure 1). The subsequent search for other bioactive peptides involves generating the sequence of the fractionated peptides and matched them to existing antimicrobial databases to identify possible antimicrobial peptides (Odintsova et al., 2009).

\section{Antifungal Assay}

Fractionated peptides were qualitatively tested for their antifungal bioactivity, specifically towards G. boninense using a microtiter plate-based assay. As indicated in Figure 2, 25\% and 30\% fractions of the trypsin hydrolysate showed inhibition of the fungus G. boninense at day 2 to day 3. Eluted fractions $10 \%$ 
and $30 \%$ of the pepsin hydrolysate also demonstrated inhibition against $G$. boninense from day 2 to day 3 . In this antifungal activity assay, we had monitored the inhibition behaviour until day 7 of the G. boninense growth. At day 7, G. boninense growth no longer show any inhibition by the peptide (for both trypsin and pepsinised) hydrolysates as the fungal growth reached saturation at day 7 . It was postulated that the dosage of the peptide hydrolysates $(10 \mu \mathrm{L})$ was enough to suppress the growth until day 3.

\section{2,2-Diphenyl-1-Picrylhydrazyl (DPPH) Free Radical Scavenging Activity Assay}

Only non-fractionated mesocarp protein hydrolysates were assayed for their scavenging activity towards DPPH. Figure 3 shows the $\mathrm{DPPH}_{\mathrm{SC}}$ of the trypsin and pepsin hydrolysates. Presence of peptides with scavenging activity of $22.3 \%$ was found in pepsin-treated mesocarp proteins after $3 \mathrm{~min}$. Trypsin-digested mesocarp

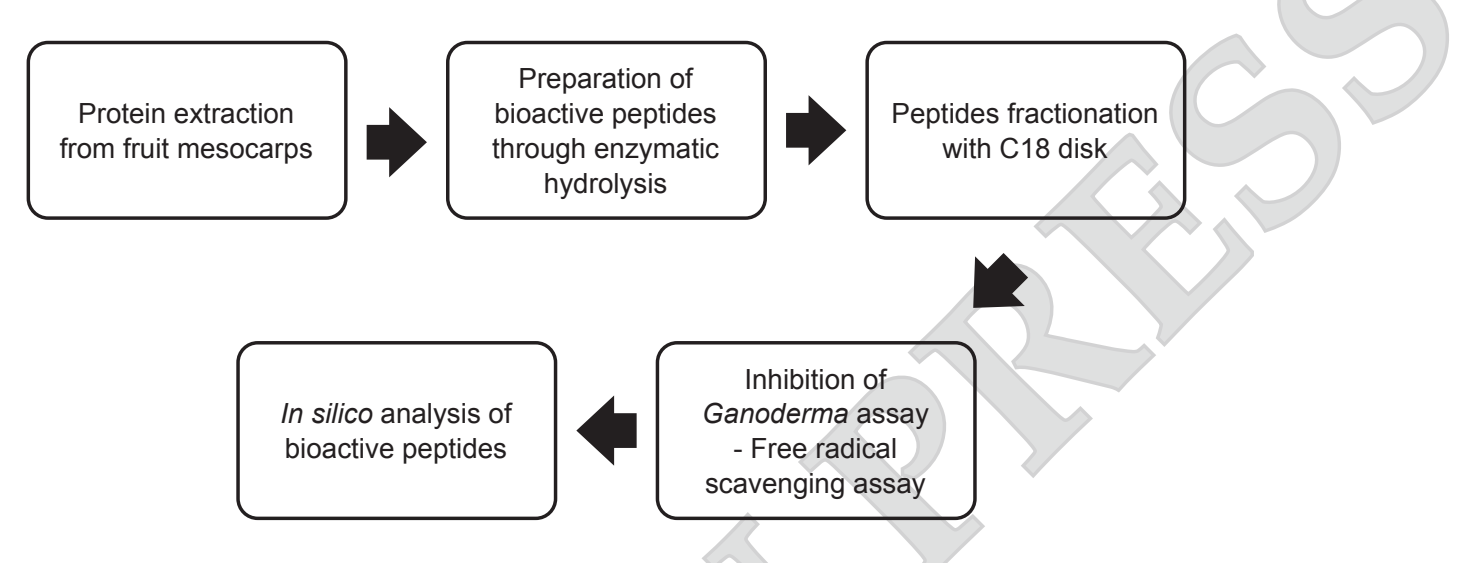

Figure 1. Overall process to generate bioactive peptides from oil palm mesocarps. The protein was extracted from the oil palm fruit mesocarps before being treated with trypsin and pepsin for enzyme hydrolysis. Then, the peptides were fractionated with C18 disk for antifungal, while the nonfractionated hydrolysates were used for antioxidant assay. The acquired peptides were further matched to the antimicrobial peptide database (APD) to determine the existence of bioactivity.

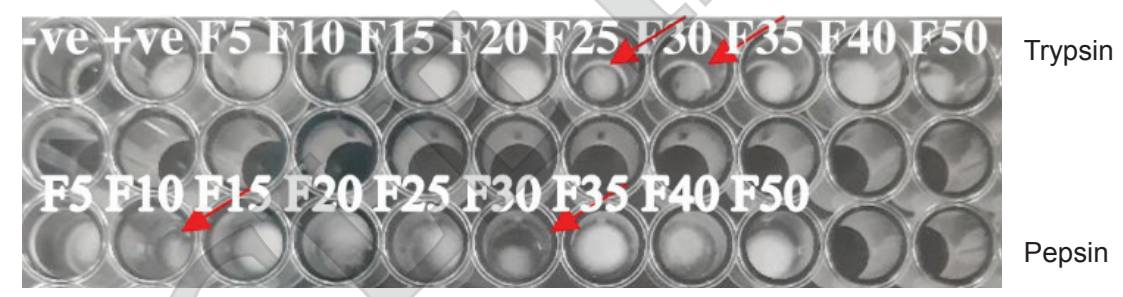

Day 2

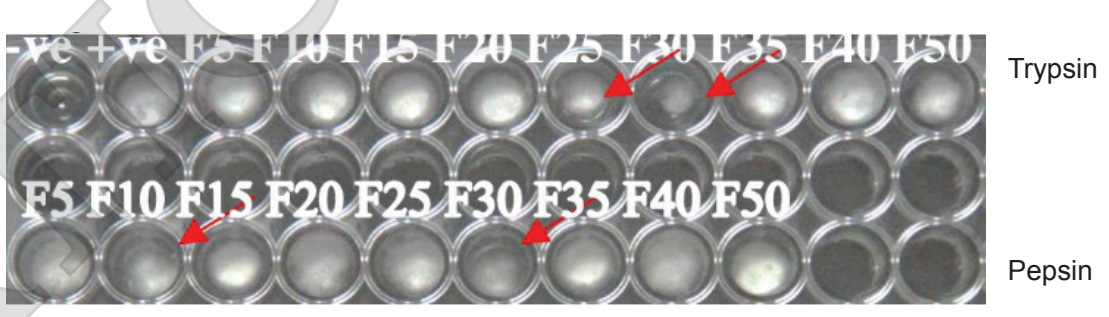

Day 3

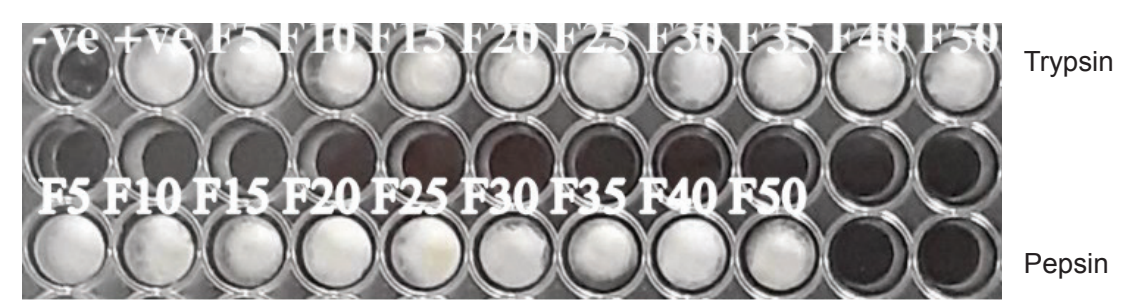

Day 7

Figure 2. Antifungal bioactivity of the fractionated peptide hydrolysates towards Ganoderma boninense until day 7 of the fungal growth. The fractionated trypsin and peptide hydrolysates (F5, F10, F15, F20, F25, F30, F35, F40 and F50) were tested for their inhibition against the Ganoderma boninense fungus. F25 and F30 of the trypsin hydrolysate showed inhibition at day 2 to day 3 . F10 and F30 of the pepsin hydrolysate also showed inhibition from day 2 to day 3. 

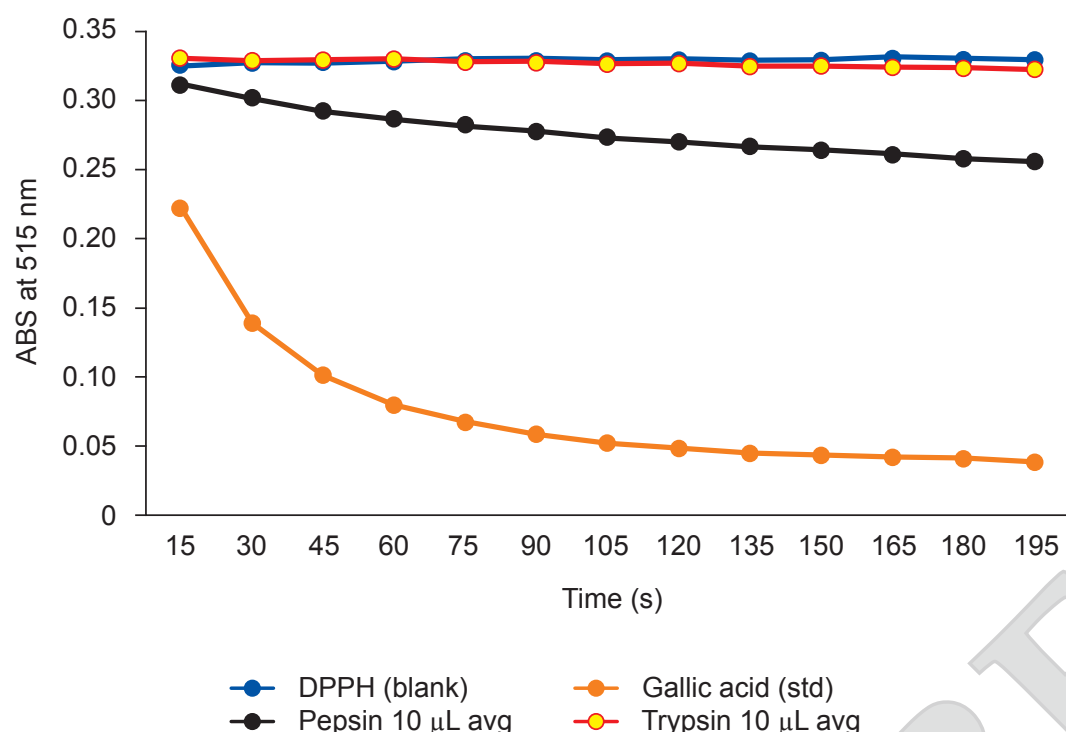

Figure 3. Free radical-scavenging activity assays of trypsin- and pepsin-treated mesocarp proteins. Gallic acid was the assay standard used and DPPH was the assay blank. Pepsin hydrolysate showed $22.3 \%$ of scavenging activity and trypsin hydrolysate exhibited a lower scavenging activity of $17.7 \%$.

proteins showed lower $\mathrm{DPPH}_{\mathrm{SC}}$ of $17.7 \%$ after 3 min. Digestion with pepsin clearly exposed more amino acid residues that could act as hydrogen donor to enhance the scavenging capability of the peptides. Digestion with trypsin resulted in peptides with higher hydrophilicity that render them inaccessible to DPPH free radicals (Bamdad et al., 2011). Both hydrolysates were filtered and supposed to comprise of peptides with masses of less than $10 \mathrm{kDa}$. Low mass peptides are normally more effective as antioxidants (Hong et al., 2014; Liu et al., 2015; Zhao et al., 2007).

\section{In Silico Identification of Peptide with Antimicrobial Bioactivity}

Sequence of the fractionated peptides was determined using shotgun proteomics strategy. Figures 4 and 5 displayed the representative peptide fragment spectra from the fractionated hydrolysates corresponding to trypsin and pepsin hydrolysis. The peptide sequences were searched against the antimicrobial database to identify peptides with bioactivities. The in silico analysis found four peptides with mass of less than 4 $\mathrm{kDa}(\mathrm{MH}+)$ obtained from the trypsin digestion matched (82\%-100\%) to known antimicrobial peptides deposited in the database. Their sequences contained 11-39 amino acid residues per peptide. Three of these peptides identified to PG-K111, Peptide 5 and lactococcin Q, possess antigram positive and negative activities while peptide NKGCAICSIGAACLVDGPIPDFEIAGATGLFGLWG (identified to subtilosin A1) from fraction $15 \%$ has anti-gram positive property only. All these peptides have high amount of hydrophobic amino acids $(23 \%-54 \%)$. The increment of these hydrophobic residues explained the higher concentration of acetonitrile to elute these bioactive peptides and their solubility in lipid. This could help in enhancing the lipid inhibitory activity by facilitating the interaction between peptides and radical species (Siow and Gan, 2013). Hydrophobic amino acid could also help to exhibit higher antihypertensive potential (Cheung et al., 1980; Ghribi et al., 2015).

Peptide sequences identified from 5\% peptide fraction of pepsin digestion were found matched to the known antimicrobial and antifungal peptides. All these peptides have mass of less than $5 \mathrm{kDa}$ $(\mathrm{MH}+)$. All the matched peptides identified to human drosomycin-like defensin, MiAMP2c and MiAMP2d, have antifungal properties except peptide RMRRSKSGKGSGGSKGSGSKGSKGSKGS GSKGSGSKGGSRPGGGSSIA GGGSKGKGGT QTA, identified to ayu cathelicidin (aCATH) peptide in the APD. Less than $25 \%$ of the peptides are made of hydrophobic amino acids and these explained the poor retention by the hydrophobic column. The in silico analysis also showed that these peptides are very long, from 48-68 amino acid residues per peptide. The peptide sequences were observed to possess a high amount of repeating amino acid residues. Many reported dipeptides from plant proteins were found to exhibit in vitro antioxidant effects (Samaraweera et al., 2011). These di- and tri-peptides have exhibited better biological activity if compared to their constituent amino acids (Kawashima et al., 1979). They are also absorbed more rapidly than free amino acid (Silk et al., 1980). 


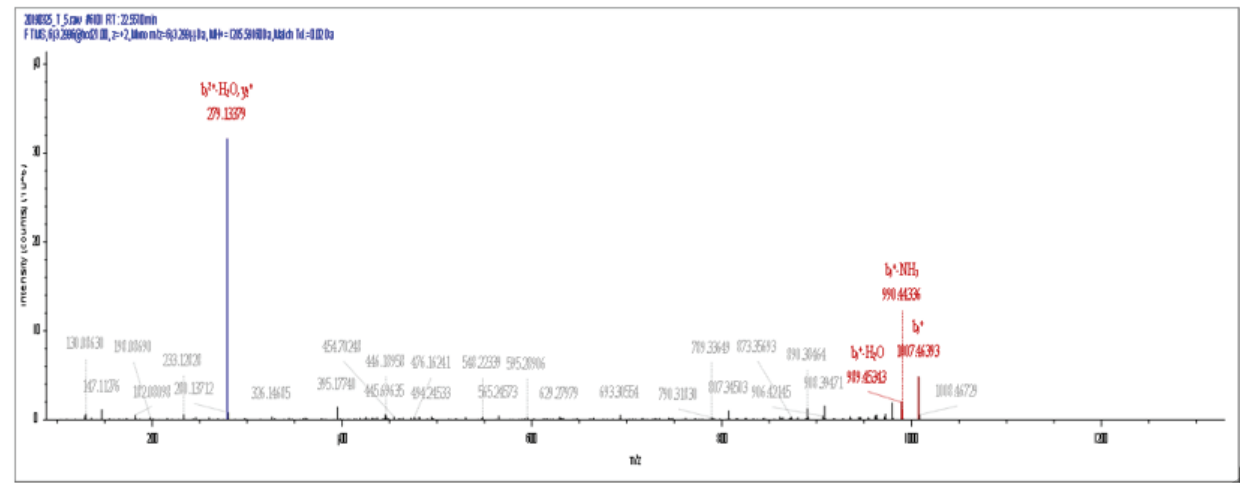

EPHPNEFVGLM (MH+: $1285.58815 \mathrm{Da}$, Fraction $5 \%$ and $20 \%$ )

$36 \%$ hydrophobic residue, length: 11 amino acid

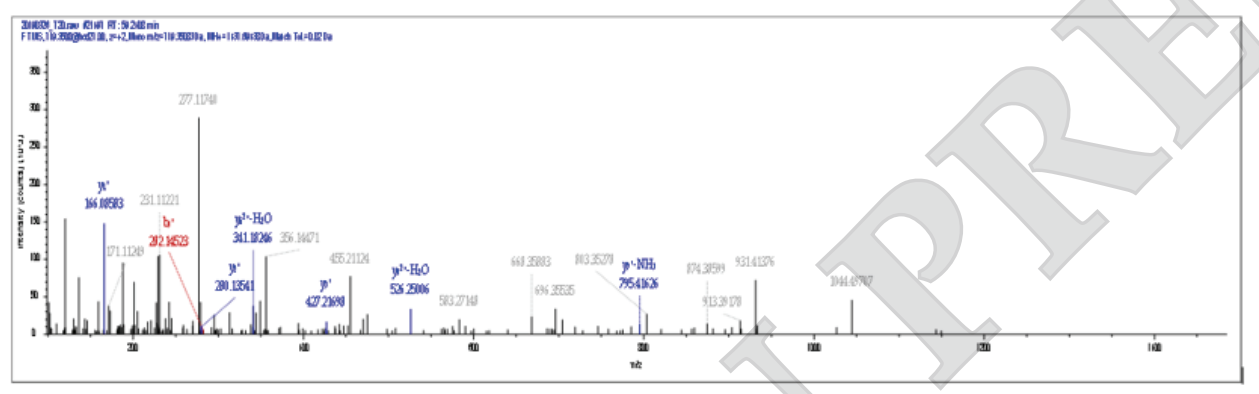

SPPSEQLGKSFNF (MH+: $1437.70087 \mathrm{Da}$, Fraction 10\%)

$23 \%$ hydrophobic residue, length: 13 amino acid

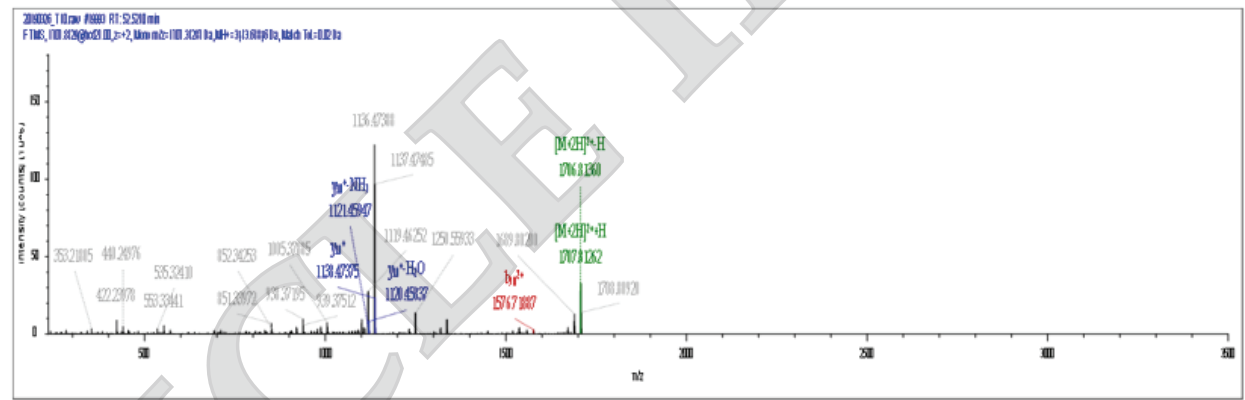

SIWGDIGQGVGKAAYWVGKAMGNMSDVNQASEINRKKKH (MH+: 3413.58890 Da, Fraction 10\%) $35 \%$ hydrophobic residue, length: 39 amino acid

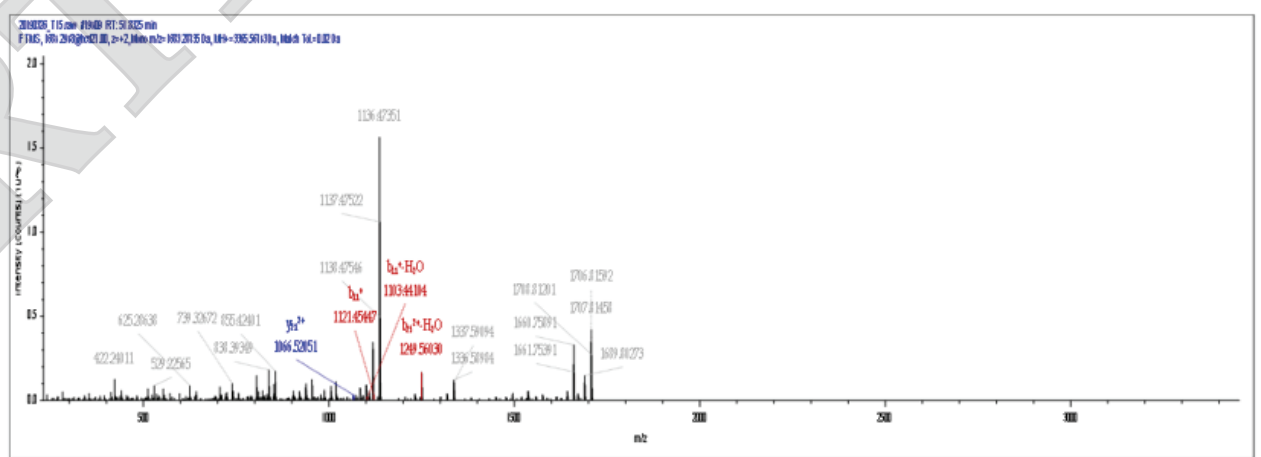

NKGCAICSIGAACLVDGPIPDFEIAGATGLFGLWG (MH+: 3365.60032 Da, Fraction 15\%)

$54 \%$ hydrophobic residue, length: 35 amino acid

Figure 4. Peptide spectra identified as bioactive peptide from 5\%,10\%,15\% and 20\% fraction of trypsin hydrolysate. The peptide sequences determined from this work were matched to known bioactive peptide sequences in Antimicrobial Peptide Database (APD). Sequence matched is in red font and underlined. The peptides were identified to PG-K111, Peptide 5, lactococcin Q and subtilosin A1. 


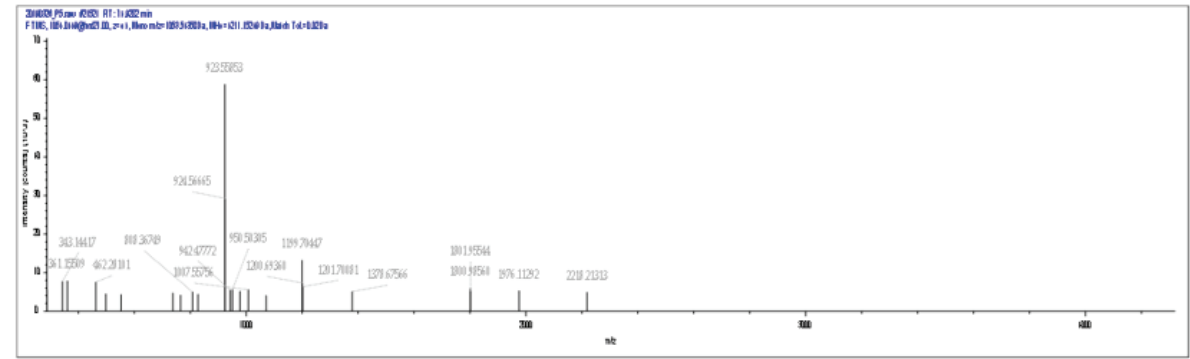

RMRRSKSGKGSGGSKGSGSKGSKGSKGSGSKGSGSKGGSRPGGGSIAGGGSKGKGGTQTA (MH+: $4211.11075 \mathrm{Da}$, Fraction 5\%)

$6 \%$ hydrophobic residue, length: 61 amino acid

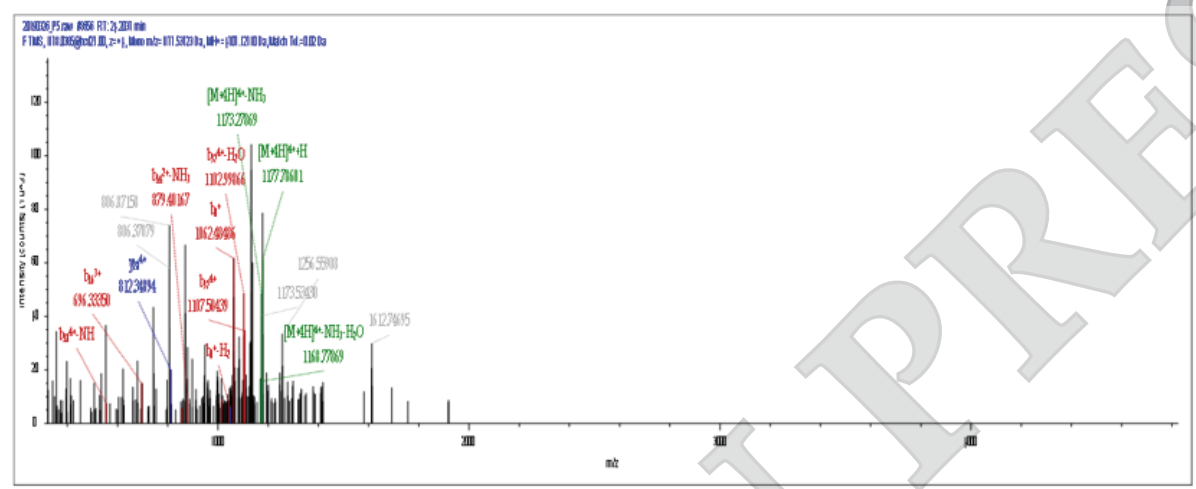

CLAGRLDKQCTCRRSQPSRRSGHEVGRPSPHCGPSRQCGCHMD (MH+: $4707.09939 \mathrm{Da}$ Fraction 5\%)

$25 \%$ hydrophobic residue, length: 43 amino acid

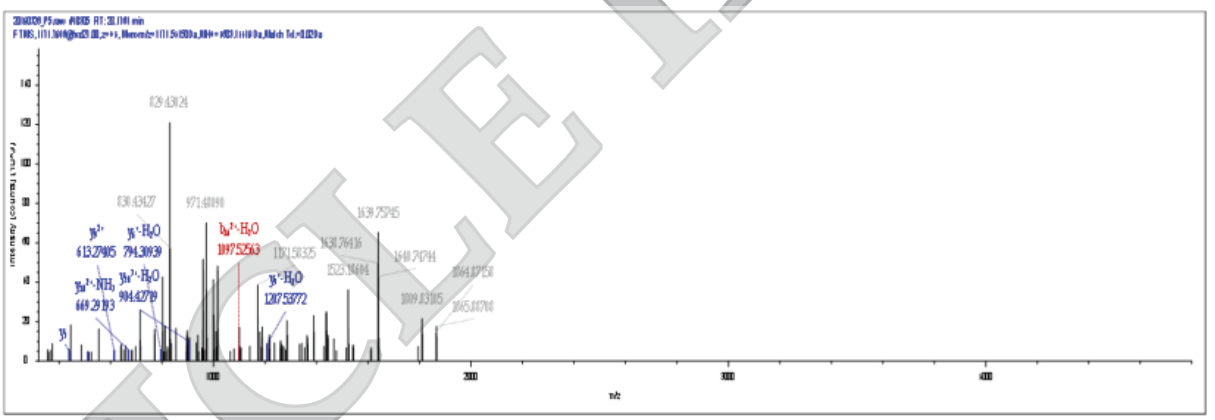

RQRDPQQQYEQCQKHCQRRETEPRHMQTCQQRCERRYEKEKRKQQKRYEEQQREDEEKY (MH+: $4683.18453 \mathrm{Da}$, Fraction 5\%)

$8 \%$ hydrophobic residue, length: 68 amino acid

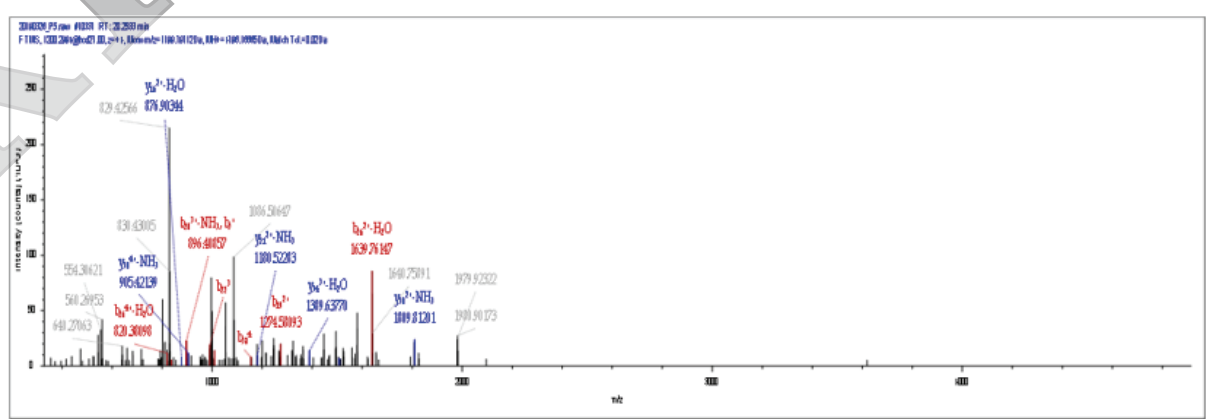

KRDPQQREYEDCRRRCEQQEPRQQHQCQLRCREQQRQHGRGGDMMNPQRGGSGRY

EEGEEEQS (MH+: 4796.17269 Da, Fraction 5\%)

$11 \%$ hydrophobic residue, length: 63 amino acid

Figure 5. Peptide spectra identified as bioactive peptide from 5\% fraction of pepsin hydrolysate. The peptide sequences determined from this work were matched to known bioactive peptide sequences in Antimicrobial Peptide Database (APD). Sequence matched is in red font and underlined. The peptides were identified to aCATH, human drosomycin-like defensin, MiAMP2c and MiAMP2d. 


\section{DISCUSSION}

This study described the isolation of peptides with validated antifungal towards G. boninense and antioxidant bioactivities from oil palm fruit mesocarp. In silico analysis also revealed the presence of antimicrobial peptides after tryptic and peptic hydrolysis of the oil palm fruit mesocarp. There is no reported study that examined the conversion of oil palm mesocarp to generate these bioactive peptides. The nearest oil palm related materials that were used to produce peptides with bioactivity were extracted from palm kernel cake and pulp (Chee et al., 2012; Ng et al., 2013; Tan et al., 2013; Zarei et al., 2015; Zheng et al., 2017).

In this work, the $25 \%$ and $30 \%$ fractions of trypsin hydrolysate were observed to suppress the growth of $G$. boninense. However, in silico analysis found four antimicrobial peptides in 5\%-20\% fractions of trypsin hydrolysate, instead. Similarly, the $10 \%$ and $30 \%$ fractions of the pepsin hydrolysate were found to suppress the fungal growth until day 3 before the effect wore out by day 7. In silico analysis identified four peptides with reported antifungal and antimicrobial activity from 5\% fraction of the pepsin hydrolysate only. The results indicated that the peptide with antifungal activity towards G. boninense could be novel and has not been reported previously. Antimicrobial and antifungal peptides are amphipathic naturally and they are made up of both hydrophilic and hydrophobic domains (Tang et al., 2018). The possible routes for the inhibition range from disintegration of cell membranes (binding to lipid bilayer structure and phospholipid groups) (Brogden, 2005; De Cesare et al., 2020; Shai, 2002) to inhibit certain key pathways in the cell such as protein synthesis (Le et al., 2017).

In the in silico analysis, peptides with antimicrobial peptides against gram-positive and gram-negative bacteria were identified from the fractionated trypsin and pepsin hydrolysates. Generally, peptides corresponding to different enzymatic hydrolysis exhibited different characteristics, in terms of their hydrophobic amino acid contents and the length of amino acid residues per peptide (Karami and Akbari-adergani, 2019). In our study, using the trypsin hydrolysis, the generated peptides were identified to PGK111, Peptide 5, lactococcin Q and subtilosin A1 in the Antimicrobial Peptide Database (APD). PG-K111 is a neuropeptide from the tachykinin family and related to kassinin, which is involved in Kassina frog's neuropeptide signaling in a defense response (Grace et al., 2001; Simmaco et al., 1990). Tachykinin-related peptides were also known to have antimicrobial activity as reported in studies on Triatoma infestans hemolymph (Diniz et al., 2020). Meanwhile, Peptide 5, a proline-rich peptide, was found to inhibit Staphylococcus aureus (Gram-positive bacteria) and Klebsiella pneumoniae (Gram-negative bacteria) (Dolashka et al., 2011). Lactococcin Q, a bacteriocin, was originally demonstrated to inhibit Lactococcus lactis strains only (Zendo et al., 2006). Later, the antimicrobial peptide was found to show high gene sequence cluster similarity to that of lactococcin G (Ishibashi et al., 2015). Subtilosin A1 is an anionic bacteriocin that showed antibacterial activity towards certain gram-positive bacteria. Subtilosin A1 was an enhanced antimicrobial peptide by substituting the threonine with isoleucine at position 6 (Huang et al., 2009). These antimicrobial peptides are believed to protect plants from invasive fungal and bacterial species. Their mode of action are believed to involve adhesion to microbial cells and penetrate the phospholipid membranes since the peptides are small in size (less than $10 \mathrm{kDa}$ ) and charge, and capable to alter hydrophobic and hydrophilic properties (Dicks et al., 2018; Meade et al., 2020). For example, studies on the mode of action by lactococcin $\mathrm{G}$ postulated that the peptide form a membrane-penetrating helix-helix structure which interacts with the membrane receptor of bacteria (Rogne et al., 2008). Lactococci was also revealed to possess antifungal by producing novel antibiotic complex against food-borne pathogens, including fungi (Stoyanova et al., 2010). Subtilosin is also found to inhibit various phytopathogenic fungi in a study on autochthonous Bacilllus subtilis isolated from Prosopis juliflora (Abdelmoteleb et al., 2017).

The enzymatic hydrolysis of oil palm fruit mesocarps with pepsin yielded four peptides identified to Plecoglossus altivelis or aCATH, human drosomycin-like defensin, MiAMP2c and MiAMP2d. Initially aCATH was found to exhibit antimicrobial activity in fish (Lu et al., 2011). A more recent studies found that cathelicidin peptides are effective against Candida species (Rapala-Kozik et al., 2015; Scarsini et al., 2015). Cathelicidins is generally thought to exhibit the antifungal activity through membrane destabilisation and internalisation (Ordonez et al., 2014). Peptide acquired from our works also matched to human drosomycin-like defensin. Defensin is known for its antifungal properties (Lacerda et al., 2014; Stotz et al., 2009). The human drosomycin-like defensin from the APD matches was found to display fungal inhibition towards Aspergillus spp. and other clinically relevant filamentous fungi (Simon et al., 2008). Similar to cathelicidins, drosomycinlike defensin, or defensin itself, interacts with the fungal target, either the cell membrane and/or the fungal cell wall (Struyfs et al., 2021). Both vicilinlike macadamia antimicrobial peptides (MiAMP2c and MiAMP2d) were found to be inhibiting 
various plant pathogenic fungi (Marcus et al., 1999), though their inhibitory mechanism is still not clear.

Many antimicrobial peptides are known to exert antioxidant bioactivity as well (MemarpoorYazdi et al., 2012). The presence of dipeptides and tripeptides in pepsin hydrolysate seemed to contribute to their antioxidant bioactivity as reported previously (Kawashima et al., 1979; Samaraweera et al., 2011; Wu et al., 2020). The result of the in silico analysis was in agreement with their free radical-scavenging activity. Nonfractionated mesocarp pepsin hydrolysate showed a $\mathrm{DPPH}_{\mathrm{SC}}$ of $22.3 \%$. The hydrophobicity of peptide is also considered as the key determinant in its antioxidant property, possibly due to the aromatic and sulphur containing structures that make them sequester radicals (Nwachukwu and Aluko, 2019; Zou et al., 2016). The high amount of hydrophobic amino acid presence in the peptides confers to better antioxidant activity. However, this was not the case with pepsin hydrolysates as the identified peptides were found to have low quantity of hydrophobic amino acid residues. This suggests that there are novel antioxidant peptides present in the pepsin hydrolysate but was not being identified through the in silico analysis.

\section{CONCLUSION}

Confirmation of the presence of bioactive peptides from oil palm fruit mesocarps indirectly indicates that the oil palm by-product wastes such as pressed mesocarp fibres, generated after the oil extraction, could potentially serve as a promising source of bioactive peptides for a sustainable and ecofriendly management of the oil palm wastes. The conversion of these mesocarp wastes to peptides with antifungal bioactivities towards $G$. boninense also presents a more direct way to control the onset of basal stem rot disease caused by G. boninense. Results from this works also suggest that protein hydrolysates from oil palm fruit mesocarps could serve as valuable functional agents in healthy diets to manage metabolic diseases that arise from excessive levels of free radicals. However, in vivo antioxidant activity of these peptides and the mechanism underlying their protection of cellular oxidative stress protection need to be explored further. In the meantime, inhibition of $G$. boninense growth by higher concentration of the fractionated hydrolysates and the potential inhibitory or control mechanisms would also be established. These peptides could be utilised to develop novel agent with biologically active component in agriculture as natural and sustainable crop protection agents.

\section{ACKNOWLEDGEMENT}

This financial support was provided through the Malaysian Palm Oil Board (MPOB) Operational Budget (RA06010001). The authors would like to thank the Director-General of MPOB for the permission to publish this article. The authors also thank the Breeding and Tissue Culture Unit and the Plant Pathology and Biosecurity Unit of MPOB for providing the oil palm fruit bunches and Ganoderma boninense culture, respectively for this work. The authors thanked Zaini Abdullah for performing the antifungal assays.

\section{REFERENCES}

Abas, R; Kamarudin, M F; Nordin, A B A and Simeh, M A (2011). A study on the Malaysian oil palm biomass sector - Supply and perception of palm oil millers. Oil Palm Industry Economic Journal, 11: 28-41.

Abdelmoteleb, A; Troncoso-Rojas, R; Gonzalez-Soto, $\mathrm{T}$ and Gonzalez-Mendoza, D (2017). Antifungical activity of autochthonous Bacillus subtilis isolated from Prosopis juliflora against phytopathogenic fungi. Mycobiology, 45: 385-391.

Bamdad, F; Wu, J and Chen, L (2011). Effects of enzymatic hydrolysis on molecular structure and antioxidant activity of barley hordein. J. Cereal Sci., 54: 20-28.

Brogden, K A (2005). Antimicrobial peptides: Pore formers or metabolic inhibitors in bacteria? Nat. Rev. Microbiol., 3: 238-50.

De Cesare, G B; Cristy, S A; Garsin, D A and Lorenz, M C (2020). Antimicrobial peptides: A new frontier in antifungal therapy. mBio, 11: e02123-20.

Chavalparit, O (2006). Clean technology for the crude palm oil industry in Thailand. Ph.D thesis, Wageningen University.

Chee, K L; Ling, H K and Ayob, M K (2012). Optimization of trypsin-assisted extraction, physico-chemical characterization, nutritional qualities and functionalities of palm kernel cake protein. LWT - Food Sci. Technol., 46: 419-427.

Cheung, H S; Wang, F L; Ondetti, M A; Sabo, E F and Cushman, D W (1980). Binding of peptide substrates and inhibitors of angiotensinconverting enzyme. Importance of the $\mathrm{COOH}-$ terminal dipeptide sequence. J. Biol. Chem., 255: 401-407. 
Dicks, L M T; Dreyer, L; Smith, C and Van Staden, A D (2018). A review: The fate of bacteriocins in the human gastro-intestinal tract: Do they cross the gutblood barrier? Front. Microbiol., 9: 2297.

Diniz, L C L; Alves, F L; Miranda, A and Da Silva Junior, P I (2020). Two tachykinin-related peptides with antimicrobial activity isolated from Triatoma infestans hemolymph. Microbiol. Insights, 13: 1178636120933635.

Dolashka, P; Moshtanska, V; Borisova, V; Dolashki, A; Stevanovic, S; Dimanov, T and Voelter, W (2011). Antimicrobial proline-rich peptides from the hemolymph of marine snail Rapana venosa. Peptides, 32: 1477-1483.

Ghribi, A M; Sila, A; Przybylski, R; Nedjar-Arroume, N; Makhlouf, I; Blecker, C; Attia, H; Dhulster, P; Bougatef, A and Besbes, S (2015). Purification and identification of novel antioxidant peptides from enzymatic hydrolysate of chickpea (Cicer arietinum L.) protein concentrate. J. Funct. Foods, 12: 516-525.

Grace, R C R; Lynn, A M and Cowsik, S M (2001). Lipid induced conformation of the tachykinin peptide Kassinin. J. Biomol. Struct. Dyn., 18: 611-625.

Hong, J; Chen, T-T; Hu, P; Yang, J and Wang, S-Y (2014). Purification and characterization of an antioxidant peptide (GSQ) from Chinese leek (Allium tuberosum Rottler) seeds. J. Funct. Foods, 10: 144-153.

Huang, T; Geng, H; Miyyapuram, V R; Sit, C S; Vederas, J C and Nakano, M M (2009). Isolation of a variant of subtilosin A with hemolytic activity. J. Bacteriol., 191: 5690-5696.

Irvan (2018). Processing of palm oil mill wastes based on zero waste technology. IOP Conf. Ser.: Mater. Sci. Eng., 2018. Sumatera Utara, Indonesia. IOP Publishing Ltd. p. 012136.

Ishibashi, N; Zendo, T; Koga, S; Shigeri, Y and Sonomoto, K (2015). Molecular characterization of the genes involved in the secretion and immunity of lactococcin Q, a two-peptide bacteriocin produced by Lactococcus lactis QU 4. Microbiology (Reading), 161: 2069-2078.

Karami, Z and Akbari-Adergani, B (2019). Bioactive food derived peptides: A review on correlation between structure of bioactive peptides and their functional properties. J. Food Sci. Technol., 56: 535-547.

Kawashima, K; Itoh, H; Miyoshi, M and Chibata, I (1979). Antioxidant properties of branched-chain amino acid derivatives. Chem. Pharm. Bull. (Tokyo), 27: 1912-1916.
Kushairi, A and Mohd Din, A (2020). Development of new oil palm cultivars in Malaysia. J. Oil Palm Res., 32: 420-426.

Lacerda, A F; Vasconcelos, E A R; Pelegrini, P B and Grossi De Sa, M F (2014). Antifungal defensins and their role in plant defense. Front. Microbiol., 5: 116.

Lau, B Y C; Deb-Choudhury, S; Morton, J D; Clerens, S; Dyer, J M and Ramli, U S (2015). Method developments to extract proteins from oil palm chromoplast for proteomic analysis. SpringerPlus, 4: 791 .

Le, C F; Fang, C M and Sekaran, S D (2017). Intracellular targeting mechanisms by antimicrobial peptides. Antimicrob. Agents Chemother., 61: e0234016.

Liu, K; Zhao, Y; Chen, F and Fang, Y (2015). Purification and identification of Se-containing antioxidative peptides from enzymatic hydrolysates of Se-enriched brown rice protein. Food Chem., 187: 424-430.

Lu, X J; Chen, J; Huang, Z A; Shi, Y H and Lv“, J $\mathrm{N}$ (2011). Identification and characterization of a novel cathelicidin from ayu, Plecoglossus altivelis. Fish Shellfish Immunol., 31: 52-57.

Marcus, J P; Green, J L; Goulter, K C and Manners, J M (1999). A family of antimicrobial peptides is produced by processing of a 7S globulin protein in Macadamia integrifolia kernels. Plant J., 19: 699-710.

Meade, E; Slattery, M A and Garvey, M (2020). Bacteriocins, potent antimicrobial peptides and the fight against multi drug resistant species: Resistance is futile? Antibiotics (Basel), 9: 32.

Memarpoor-Yazdi, M; Asoodeh, A and Chamani, J (2012). A novel antioxidant and antimicrobial peptide from hen egg white lysozyme hydrolysates. J. Funct. Foods, 4: 278-286.

$\mathrm{Ng}, \mathrm{K}$ L; Ayob, M K; Said, M; Osman, M A and Ismail, A (2013). Optimization of enzymatic hydrolysis of palm kernel cake protein (PKCP) for producing hydrolysates with antiradical capacity. Ind. Crops Prod., 43: 725-731.

Nwachukwu, I D and Aluko, R E (2019). Structural and functional properties of food proteinderived antioxidant peptides. J. Food Biochem., 43: e12761.

Odintsova, T I; Vassilevski, A A; Slavokhotova, A A; Musolyamov, A K; Finkina, E I; Khadeeva, N V; Rogozhin, E A; Korostyleva, T V; Pukhalsky, V 
A; Grishin, E V and Egorov, T A (2009). A novel antifungal hevein-type peptide from Triticum kiharae seeds with a unique 10-cysteine motif. FEBS J., 276: 4266-4275.

Ordonez, S R; Amarullah, I H; Wubbolts, R W; Veldhuizen, E J and Haagsman, H P (2014). Fungicidal mechanisms of cathelicidins LL-37 and CATH-2 revealed by live-cell imaging. Antimicrob. Agents Chemother., 58: 2240-2248.

Pereira, P H F; Souza, N F; Ornaghi Jr, H L and De Freitas, M R (2020). Comparative analysis of different chlorine-free extraction on oil palm mesocarp fiber. Ind. Crops Prod., 150: 112305.

Rapala-Kozik, M; Bochenska, O; Zawrotniak, M; Wolak, N; Trebacz, G; Gogol, M; Ostrowska, D; Aoki, W; Ueda, M and Kozik, A (2015). Inactivation of the antifungal and immunomodulatory properties of human cathelicidin LL-37 by aspartic proteases produced by the pathogenic yeast Candida albicans. Infect. Immun., 83: 2518-2530.

Rogne, P; Fimland, G; Nissen-Meyer, J and Kristiansen, PE (2008). Three-dimensional structure of the two peptides that constitute the two-peptide bacteriocin lactococcin G. Biochim. Biophys. Acta, 1784: 543-554.

Sabil, K M; Aziz, M A; Lal, B and Uemura, Y (2013). Effects of torrefaction on the physiochemical properties of oil palm empty fruit bunches, mesocarp fiber and kernel shell. Biomass Bioenergy, 56: 351-360.

Samaraweera, H; Zhang, W G; Lee, E J and Ahn, D U (2011). Egg yolk phosvitin and functional phosphopeptides--Review. J. Food Sci., 76: R143-150.

Scarsini, M; Tomasinsig, L; Arzese, A; D'este, F; Oro, D and Skerlavaj, B (2015). Antifungal activity of cathelicidin peptides against planktonic and biofilm cultures of Candida species isolated from vaginal infections. Peptides, 71: 211-221.

Shai, Y (2002). Mode of action of membrane active antimicrobial peptides. Biopolymers, 66: 236-248.

Silk, D B; Fairclough, P D; Clark, M L; Hegarty, J E; Marrs, T C; Addison, J M; Burston, D; Clegg, K M and Matthews, D M (1980). Use of a peptide rather than free amino acid nitrogen source in chemically defined 'elemental' diets. JPEN J. Parenter. Enteral Nutr., 4: 548-553.

Simmaco, M; Severini, C; De Biase, D; Barra, D; Bossa, F; Roberts, J D; Melchiorri, P and Erspamer, V (1990). Six novel tachykinin- and bombesin-related peptides from the skin of the Australian frog Pseudophryne güntheri. Peptides, 11: 299-304.

Simon, A; Kullberg, B J; Tripet, B; Boerman, O C; Zeeuwen, P; Van Der Ven-Jongekrijg, J; Verweij, P; Schalkwijk, J; Hodges, R; Van Der Meer, J W and Netea, M G (2008). Drosomycin-like defensin, a human homologue of Drosophila melanogaster drosomycin with antifungal activity. Antimicrob. Agents Chemother., 52: 1407-1412.

Siow, H L and Gan, C Y (2013). Extraction of antioxidative and antihypertensive bioactive peptides from Parkia speciosa seeds. Food Chem., 141: 3435-3442.

Sreekala, M S; Kumaran, M G and Thomas, S (1997). Oil palm fibers: Morphology, chemical composition, surface modification, and mechanical properties. J. Appl. Polym. Sci., 66: 821-835.

Stotz, H U; Thomson, J G and Wang, Y (2009). Plant defensins: Defense, development and application. Plant Signal. Behav., 4: 1010-1012.

Stoyanova, L G; Ustyugova, E A; Sultimova, T D; Bilanenko, E N; Fedorova, G B; Khatrukha, G S and Netrusov, A I (2010). New antifungal bacteriocinsynthesizing strains of Lactococcus lactis ssp. lactis as the perspective biopreservatives for protection of raw smoked sausages. Amer. J. Agric. Biol. Sci., 5: 477-485.

Struyfs, C; Cammue, B P A and Thevissen, K (2021). Membrane-interacting antifungal peptides. Front. Cell Dev. Biol., 9: 649875.

Tadesse, S A and Emire, S A (2020). Production and processing of antioxidant bioactive peptides: A driving force for the functional food market. Heliyon, 6: e04765.

Tan, Y N; Ayob, M K and Wan Yaacob, W A (2013). Purification and characterisation of antibacterial peptide-containing compound derived from palm kernel cake. Food Chem., 136: 279-284.

Tang, S S; Prodhan, Z H; Biswas, S K; Le, C F and Sekaran, S D (2018). Antimicrobial peptides from different plant sources: Isolation, characterisation, and purification. Phytochemistry, 154: 94-105.

Wang, G; Li, X and Wang, Z (2016). APD3: The antimicrobial peptide database as a tool for research and education. Nucleic Acids Res., 44: D1087-1093.

Wu, M; Zhu, Z; Li, S; Cai, J; Cong, X; Yu, T; Yang, W; $\mathrm{He}, \mathrm{J}$ and Cheng, $S$ (2020). Green recovery of Se-rich 
protein and antioxidant peptides from Cardamine violifolia: Composition and bioactivity. Food Biosci., 38: 100743.

Zarei, M; Forghani, B; Ebrahimpour, A; AbdulHamid, A; Anwar, F and Saari, N (2015). In vitro and in vivo antihypertensive activity of palm kernel cake protein hydrolysates: Sequencing and characterization of potent bioactive peptides. Ind. Crops Prod., 76: 112-120.

Zendo, T; Koga, S; Shigeri, Y; Nakayama, J and Sonomoto, K (2006). Lactococcin Q, a novel two-peptide bacteriocin produced by Lactococcus lactis QU 4. Appl. Environ. Microbiol., 72: 3383-3389.
Zhao, Y; Li, B; Liu, Z; Dong, S; Zhao, X and Zeng, $M$ (2007). Antihypertensive effect and purification of an ACE inhibitory peptide from sea cucumber gelatin hydrolysate. Process Biochem., 42: 1586-1591.

Zheng, Y; Li, Y; Zhang, Y; Ruan, X and Zhang, R (2017). Purification, characterization, synthesis, in vitro ACE inhibition and in vivo antihypertensive activity of bioactive peptides derived from oil palm kernel glutelin-2 hydrolysates. J. Funct. Foods, 28: 48-58.

Zou, T B; He, T P; Li, H B; Tang, H W and Xia, E $Q$ (2016). The structure-activity relationship of the antioxidant peptides from natural proteins. Molecules, 21: 72. 